\title{
HISTORIC BUILDINGS OF THE WARSAW UNIVERSITY OF TECHNOLOGY - SELECTED ISSUES OF RENOVATION, MODERNISATION AND ADAPTATION
}

\author{
Anna Agata WAGNER ${ }^{1}$, \\ Warsaw University of Technology, Warszawa, Poland
}

\begin{abstract}
The historic buildings of the Warsaw University of Technology display not only outstanding architectural values, but are also representative of the trends in preservation, restoration, and adaptation that were prevalent at the time of their modernization. The post-war rebuilding of the WUT was more akin to modernization than reconstruction. But the freedom to shape modern architectural forms in the 1960s and '70s brought with it a lack of respect for their historic environment. A change in the approach to historic buildings and their integration with modern architecture came in the late 1970s. The most recent modernization of the WUT's historic buildings, especially after Poland's accession to the EU, resulted in many good examples of proper, harmonious integration between the 'modern' and the 'traditional'.
\end{abstract}

Keywords: historic buildings of the Warsaw University of Technology, modernisation, renovation, adaptation.

\section{HISTORIC BUILDINGS OF THE WARSAW UNIVERSITY OF TECHNOLOGY}

The oldest buildings of the historic Warsaw University of Technology, along with the area between Nowowiejska, Noakowska and Koszykowa streets and Niepodległości avenue, is currently under conservation protection. It is also a

\footnotetext{
${ }^{1}$ Corresponding author: Warsaw University of Technology, Faculty of Architecture, Koszykowa st 55, 00-659 Warszawa, e-mail: agata.wagner@ arch.pw.edu.pl, tel. 603748018
} 
good example of the change in approach to the renovation and modernization of the university's buildings.

The university and its grounds were formed over the last hundred years, and at their core are several buildings constructed at the turn of the 20th century for the Russian-language Polytechnic Institute. These buildings were built relatively soon after the creation of the technical university, at a time when late historicism dominated architecture. The Polytechnic Institute was designed by two of the greatest Warsaw architects of late 19th/early 20th century - Stefan Szyller and Bronisław Brochwicz-Rogóyski.

The most important architectural developments in the interwar years took place at a time of great change in Polish and European architecture, with the search for new forms appropriate to modern materials, construction methods and aesthetics. The latter of which rejected excessive decoration. During this period the architectural and spatial development of the Technical University was shaped by several leading Warsaw architects - Tadeusz Zieliński, Karol Jankowski, Czesław Przybylski - associated with the Warsaw University of Technology (founded in 1915) and its Faculty of Architecture.

The post-war efforts to reconstruct, expand and modernize the university and its grounds were also representative of the period in which they were carried out, reflecting not only the then-current trends in architecture, but also in the renovation and modernization of historic buildings.

\subsection{The Mechanics Building}

The Mechanics Building was built in 1899-1902, during the first stage of development of today's Warsaw University of Technology, which was principally designed by Bronisław Brochwicz-Rogóyski. It is an irregular design consisting of three pavilions. The three-storey, symmetrical middle pavilion was dedicated mainly to teaching rooms. The side wings, of uneven length, and a hall-type construction housed the machinery servicing the university complex, and at the same time provided an opportunity for the students to use and observe them, for teaching purposes. During World War II, the central wing of the Mechanics Building and the Boiler Room were slightly damaged. The western wing was left with only its surrounding walls, with a total lack of roofing or interior floors, and so it was decided not to rebuild it. In the 1970s a modernist, multi-storey building (home to the current Faculty of Environmental Engineering) was built in this place. This newer building is characterized by a complete lack of other architectural references, even the principle of contrast in relation to the neighbouring historic buildings.

The lack of respect for historic architectural substance, so typical of this period, was manifested in an extreme way in the devastation of the adjacent Old Boiler 
Room, then home to the Repair and Utility department. During the 'repairs' conducted in the 1970s, its spatial layout and war-damaged elevations were partially changed, particularly the northern façade. Fortunately, the end of the 1970s brought a change in approach to historic architecture. A striking example of this new thinking was put in place twenty years later, from 1996-1997, when the damaged façade of the Old Boiler Room was cleaned (Fig. 1) and the interior modernized for the teaching purposes of the Faculties of Environmental Engineering and Electrical Engineering (design: Architect Hanna Czajkowska, 1995).
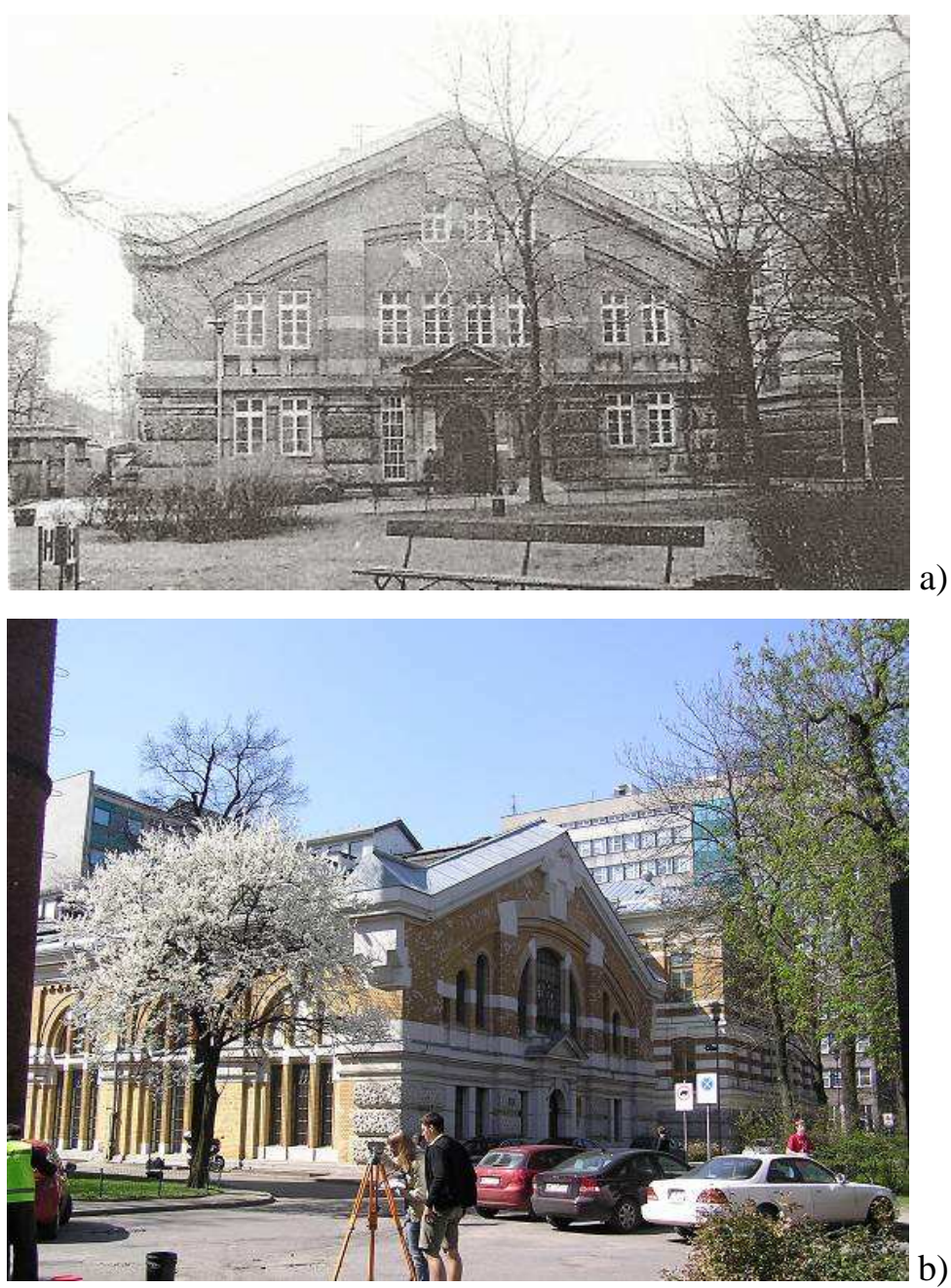

Fig. 1. The Old Boiler Room building: a) after the 1970s' 'renovation' b - Current condition. Photos: A. Wagner, 1994; 2012 


\subsection{Main Building}

The main building is representative of the Warsaw University of Technology as a whole. It was built at the turn of the 20th century for the Russian-language Warsaw Polytechnic Institute, designed by Stefan Szyller. It is a typical example of late historicism, drawing on the Italian Renaissance style and classicising Baroque. The character of the main building is emphasized by its monumental, two-storey entrance façade, with rounded corners, opening onto a square, and an extensive foyer leading to a great assembly hall - with an internal, arcaded courtyard, covered with a glass-roofed steel structure.

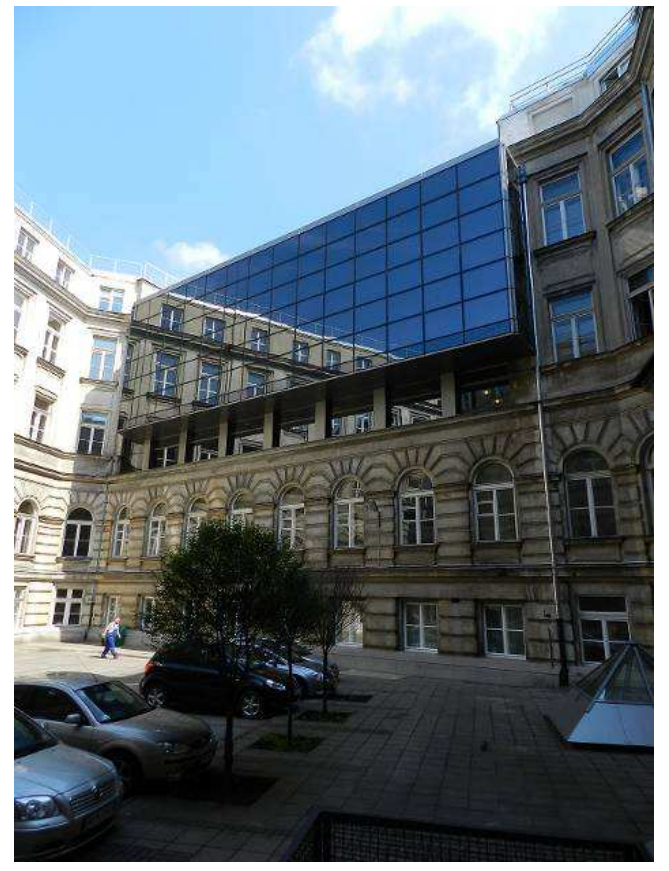

Fig. 2. Main Building. Internal view with super-structured library in 1996-1998.

Fig. A. Wagner, 2014

Originally, the main building was built without the south-western corner, implementation of which Stefan Szyller provided for in the event of the further development of the university. This expansion then actually occurred in line with the original design from 1947-1950, during the main building's reconstruction after the war. The bombed internal wing was reproduced without the two upper floors. Major modernization works in the Main Building were initiated in the 1990s. In 1994 the glass roof was reconstructed over the cloister courtyard, and in 1996-1998 saw the central wing extended to include space for a new library (done to a design by a team led by the architect Hanna 
Czajkowska). Instead of the pre-war Szyller design, a modern architectural form was proposed, that would not disturb the overall historic character of the Main Building with its location between the two inner courtyards (Fig. 2). In 2012, the interior cloister courtyard was revitalised, exposing underlying layers of paint and decorative elements made of sandstone. The following year, a modern elevator was put into use, accessible from the internal level of the northern courtyard, which significantly increased access to the building, especially for the disabled. Renovation of the façade was then completed in summer 2014. Covering-over of the interior courtyards is also being considered, which would greatly increase the usable floor area of the building (Fig. 3).

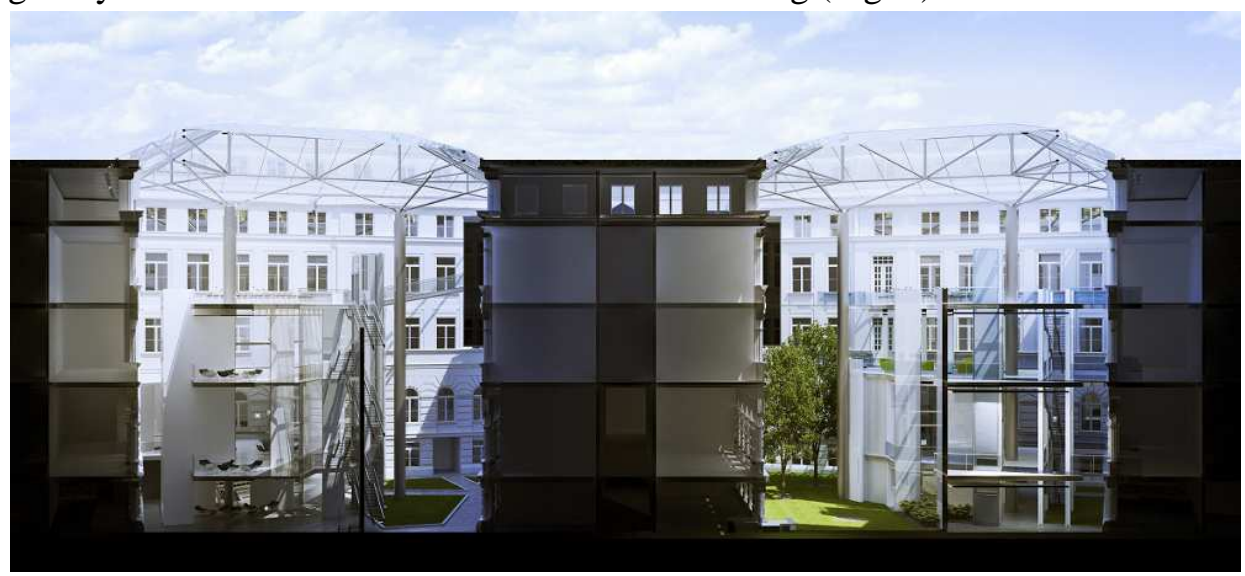

Fig. 3. Courtyard roofing designs for the Main Building, according to a concept by Prof. Lech Kłosiewicz

\subsection{The Physics Building}

The Physics Building was one of the first Warsaw University of Technology buildings, and is also the best representative of the transformation that has taken place at the university over the last few decades.

Completed at the beginning of the 20th century in the spirit of the architecture of late historicism, it combined new functional, spatial and technological thinking with a historicist's design (Fig. 4), but was seriously damaged during the war. The destroyed front wing with its large auditorium was replaced with a new part that has altered dimensions, a different room layout and a façade that is also different from the original. Its simple design and low level of detailing were the result mainly of the post-war conditions under which reconstruction of the university was carried out, highlighting the individuality of the new construction while also adapting it suit the historic character of the building (Fig. 5). 
The building was again comprehensively renovated, in more recent years. The opening ceremony of the newly-restored Physics Building took place in 2001, under the direction of Prof. Lech Kłosiewicz. First of all, this included modernization of the glass roof structure. The glass panes were replaced by two-chamber polycarbonate panes which reduced the load on the roof while meeting the requirements of thermal insulation, largely eliminating the original problem of condensation. The milky, reinforced glass ceiling was replaced by a hardened, colourful ceiling decorated in pastel shades of pink and soft blue, which according to the designer are intended to create associations with the colours of the sky. The interior of the auditorium was given new values with the introduction of various small changes. Modern construction standards called for the gallery railings on the first and second floors to be raised, with the addition of brass handrails and stone pillars separating the railings on the top floors, finished with spherical caps. On the capitals of the cloister pillars on the first floor - which during the post-war reconstruction were given simplified forms instead of the usual Ionic - ankle-like, stucco decoration with stylized acanthus leaves was applied. The original, damaged ceramic-tile flooring in the hall was replaced with stone and marble, the divisions between which reflect the architectural composition of the interior. The original terracotta flooring was preserved in the first floor gallery. Also, part of the entrance to the building and the research and teaching facility was modernized. Providing the building with a modern infrastructure and modernized interior often meant replacing the ceilings and installing new replicas of the existing doors and windows.

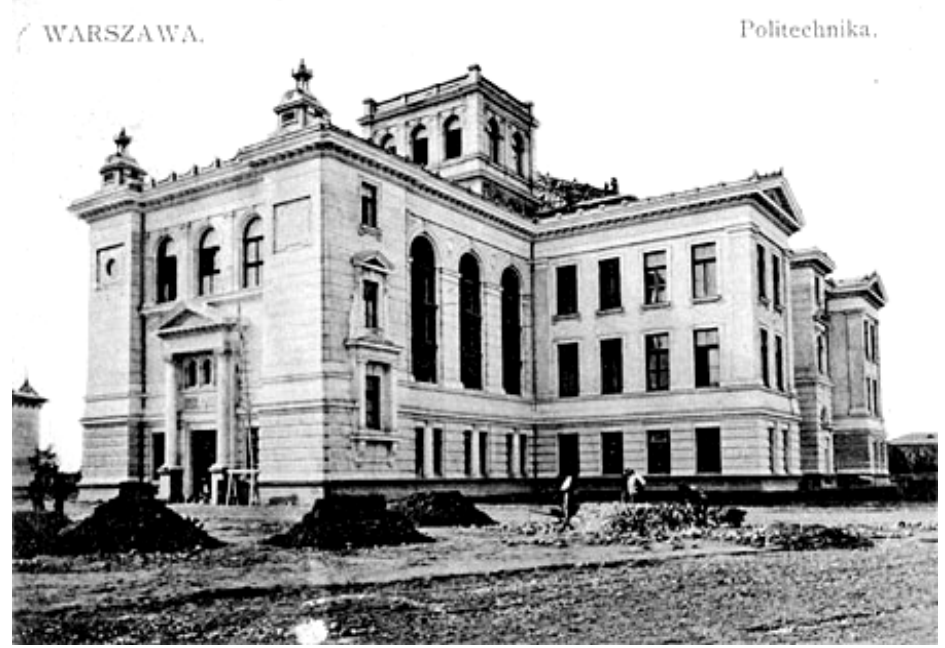

Fig. 4. The Physics and Electrical Engineering Pavilion at the Polytechnic Institute of Warsaw, Architect St. Szyller. Postcard from the collection of the Museum of the Polytechnic Institute of Warsaw 
At the beginning of 2012, the renovations to the façade were completed. Analysis and design activities are now in progress, for construction of an additional laboratory pavilion on the north side of the building. The plan is to build one storey above ground, and one under, with a garden on the roof. The new cubature, by Prof. Lech Kłosiewicz, would represent a kind of dialogue with the Physics building, drawing on historic forms, but executed in different materials and with the use of modern technology (Fig.6).

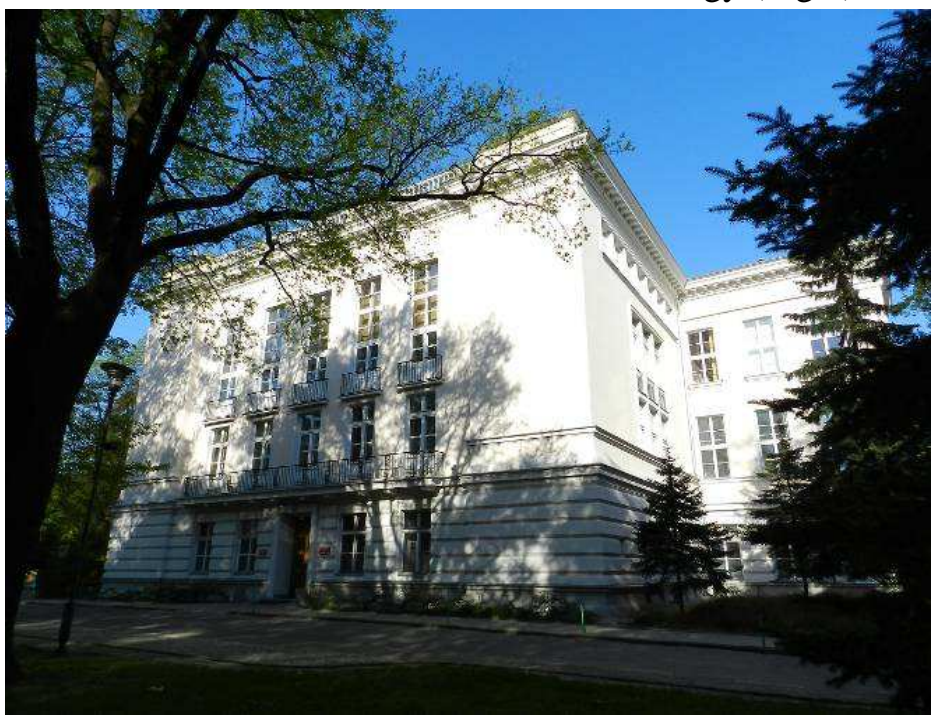

Fig. 5. The Physics Building, front wing as completed in the 1950s. Fig. A. Wagner, 2012

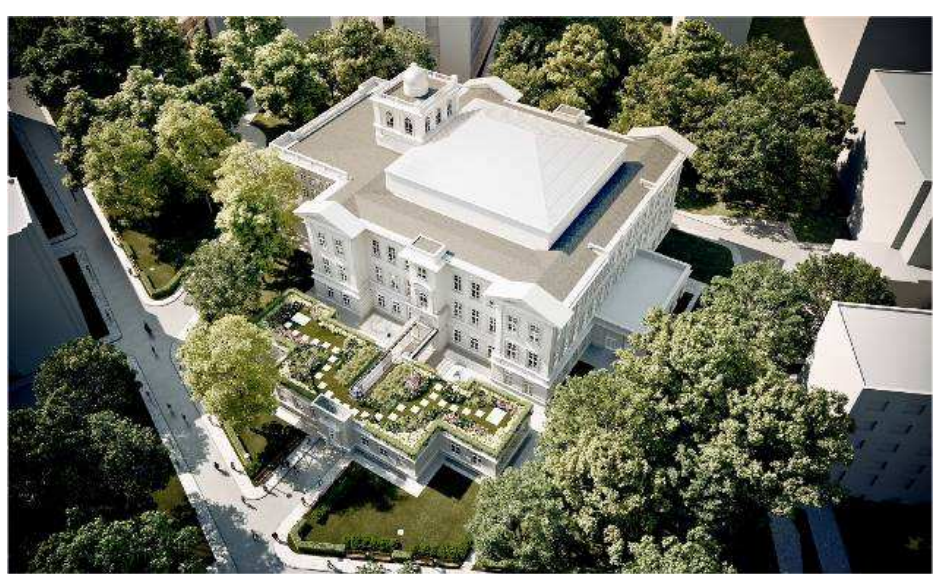

Fig. 6. The Physics Building, front wing acc. to a concept by Prof. L. Kłosiewicz 


\section{CONCLUSIONS}

The contemporary architectural and urban image of the Warsaw University of Technology is the result of post-war reconstruction of destroyed buildings, often combined with their expansion, with later modernization and implementation of new facilities. Interference with the external shape of the architectural forms of some of its historic buildings is due to deficiencies in certain facilities and the need to increase the usable area of the buildings. Changes to interiors have been dictated by the need to modernize, resulting from the natural aging of the buildings and their fixtures.

The post-war reconstruction of the historic buildings of the Warsaw University of Technology was more akin to modernization than reconstruction, as the main emphasis was on improving and intensifying their utilitarian functions, not to directly restoring their historic forms. This has created a clear, though not so strong, division between the old and new among the historic buildings. The 1950 s brought with them 'socialist realism' architecture, based on Renaissance and Classicism, melted into the WUT using traditional designs and material solutions.

A response to the imposed historicism of the 1950s can be seen in the new work done in the following decades. Freedom in the development of modernist architectural forms, limited only by technical and material shortages, caused new formal and programme concepts to lessen the importance of integration with the existing historic tissue. Further change in the approach to historic buildings and their integration with modern architecture came in the late 1970s, which began with a period of appreciation and respect for the architecture of the preceding, modernist era.

The last few decades, especially since Poland's accession to the European Union and the consequent possibility of EU funding, have resulted in a lot of modernization works to the University's buildings.

Many of the buildings, especially the older, historic ones, have undergone renovation. Historic interiors and façades have been restored to their original lustre. For many, the word façade is quite literal here, as they have also been provided with stunning night-time illuminations. Most of the university buildings had already been given a modern infrastructure, which was then adapted to the needs of people with disabilities. In addition, designs and analyses have been prepared for modernization of the other buildings, often with the aim of restoring its original, historic character and to examine the feasibility of expansion. All this work is done to help integrate modern architecture with the historic architecture of the university and its grounds. This integration should be based on a thorough analysis, knowledge of and respect 
for the historic architecture, with a precise understanding of the needs of today's users and the application of modern materials and technology.

In examining the needs of and trends at the Warsaw University of Technology, it is not only the need to modernize and enhance the functions of its office space that is taken into account, but also the protection of cultural heritage. This is part of the inclusion of the university in the life and ongoing development of the city, and also the development of integrated, landscaped outdoor areas ensuring the continuity of the urban space. As a result, the last re-evaluation of the Main Area of the Warsaw University of Technology led to it becoming even more attractive, offering values associated with the idea of promoting science at the highest level, but also respite, amongst the magnificent architecture and beautiful greenery.

\section{REFERENCES}

1. Kadłuczka A.: Problemy integracji architektury wspótczesnej $z$ historycznym środowiskiem kulturowym, Politechnika Krakowska, Kraków 1982.

2. Kucza-Kuczyński K.: Zasady modernizacji architektonicznej szkót wyższych, w: „Studia i projekty”, Politechnika Warszawska, Warszawa 1978.

3. Małachowicz E.: Konserwacja i rewaloryzacja architektury $w$ środowisku kulturowym, Oficyna Wydawnicza Politechniki Wrocławskiej, Wrocław 2007.

4. Wagner A. A.: Architektura Politechniki Warszawskiej, Oficyna Wydawnicza Politechniki Warszawskie, Warszawa, 2001.

ZABYTKOWY ZESPÓŁ GMACHÓW POLITECHNIKI WARSZAWSKIEJ WYBRANE ZAGADNIENIA ZWIAZZANE Z RENOWACJĄ, MODERNIZACJĄ I ROZBUDOWĄ

Streszczenie

Najstarszy, zabytkowy zespół Politechniki Warszawskiej, objęty obecnie wraz z terenem (między ulicami Nowowiejska, Noakowskiego, Koszykową i Alejami Niepodległości) ochroną konserwatorska, jest dobrym przykładem na ukazanie zmiany podejścia do zagadnień i działań związanych z renowacją i modernizacją historycznych zespołów uczelni wyższych. Powojenna odbudowa zabytkowych gmachów Politechniki Warszawskiej bliższa była modernizacji, niż rekonstrukcji, ponieważ główny nacisk 
położony został na usprawnienie i intensyfikację funkcji utylitarnych, a nie bezpośrednie odtwarzanie form historycznych. Odreagowaniem na narzucony historyzm lat 50. były obiekty powstałe w kolejnych dekadach. Swoboda w kształtowaniu form architektonicznych, ograniczona jedynie niedostatkami technicznymi i materiałowymi, spowodowała, iż nowe koncepcje formalne i programowe zepchnęły aspekt integracji z istniejąca zabytkową tkanką na dalszy plan. Koniec lat siedemdziesiątych przynosi zmianę podejścia do architektury zabytkowej i jej integracji z obiektami współczesnymi. Ostatnie dekady, zwłaszcza po przystąpieniu Polski do Unii Europejskiej i wiążące się z tym możliwości korzystania $z$ unijnego dofinansowania, zaowocowały wieloma pracami modernizacyjnymi gmachów Politechniki, przeprowadzanymi według obowiązujących zasad koserwatorskich.

Słowa kluczowe: (zabytkowe gmachy Politechniki Warszawskiej, modernizacja, renowacja, adaptacja).

Editor received the manuscript: 18.02 .2015 